\title{
The Exposure of Albanian Firms to the Exchange Rate Risk and Its Hedging
}

\section{Kleida Tufi Heta, PhD candidate}

\author{
Lecturer of Finance at University of Shkodra "L. Gurakuqi" \\ tufikledi@yahoo.com
}

\section{Besforta Mulleti}

\author{
Part-Time Lecturer of Finance at University of Shkodra "L. Gurakuqi"
} besfortamulleti@yahoo.com

\section{Doi:10.5901/ajis.2013.v2n9p745}

\begin{abstract}
Foreign exchange is among the most important risks facing most economic agents, whether they are corporations, institutional investors, or households. In recent times, the volatility of these rates has increased substantially and, as a result, agents have a greater need to hedge against these risks. In today's business environment, firms find it necessary to hedge the exchange rate risk, which has a big impact in their earnings. This risk affects not only firms engaged in international business but even those operating only in their local markets. Albanian businesses face a high rate of exchange rate risk due to strong business relationships with neighbor countries and broader. Hedging this risk is difficult because in a developing country like Albania, currency derivative market does not exist. The nonfunctioning of Tirana stock exchange, the fact that commercial banks still do not offer forward contract widely, and the lack of financial knowledge among businesses' representatives are among the reasons that makes hedging so difficult in our country. This paper investigates to what extend Albanian businesses face exchange rate risk, and how these businesses hedge it. We have considered a case study from an Albanian firm and found out the ways they protect their earnings from this risk. One concerning finding is that Albanian firms do not hedge financially the exchange rate exposure, even though they have a large degree of exposure. At the end we conclude by developing a framework for currency hedging to be applied from these firms in order to reduce their currency exposure.
\end{abstract}

\section{Introduction}

Foreign exchange rate risk is one of the risks that companies are becoming more and more concerned. In nowadays economic environment, where international companies and international trade have expanded like never before, this risk is a real threaten to the firm's income and its value.

Financial institutions have been creating different hedging instruments for the exchange rate risk, and firms have different alternatives to hedge according to the kind of exposure they face. But even firms themselves can follow some strategies to hedge this risk.

Options and futures for major currencies are traded widely on different stock exchanges, but what happens with minor currencies for which there are no options, futures or forwards?

In this paper we review types of exchange rate exposure and also hedging techniques. We will focus mainly on minor currency hedging and illustrate to what extent firms in Albania are exposed and what do these firms do to hedge this risk.

This paper is organized as following: In section II we have made a literature review on what exchage risk is, its types, how to assess it and ways to hedge it. In section III we describe the methodology used and describe the analysis made and the results found. In section IV we give some conclusions and some modest recommendations.

\section{Literature review}

Exchange rate risk can be broadly defined as the risk that a company's performance will be affected by exchange rate movements, (Madura 2008). In particular, it is defined as the passible direct loss (as a result of an unhedged exposure) or indirect loss in firm's cash flows, assets and liabilities, net profit, and in turns its stock market value from exchange rate move (Papaioannou 2006). Financial managers should understand and determined the type of exchange exposure the firm is facing, the hedging strategy to be used and the available instruments. 
According to Adler and Dumas (1984), currency risk exposure is to be identified with statistical quantities which summarize the probability that the actual domestic purchasing power of home or foreign currency on a given future date will differ from its originally anticipated value. Exposure, in contrast, should be defined in terms of what one has at risk. In this way, managers should know how to measure it.

Shapiro (1996), Eun \& Resnick (2004), Madura (2008), identify three main types of exchange rate exposure:

Economic exposure is defined as the extent to which the value of the firm would be affected by unanticipated changes in exchange rates.

Transaction exposure is defined as the sensitivity of "realized" domestic currency value of the firm's contractual cash flows denominated in foreign currencies to unexpected exchange rate changes. Translation exposure refers to the potential that the firm's consolidated financial statements can be affected by changes in exchange rates.

When firms are affected by exchange rate exposure, they should determine what kind of exposure that is, they should assess it, and then decide whether or not to insulate against it. Economic exposure can be measured by using (1) sensitivity analysis and (2) by using a regression analysis (Madura 2008). The first method consists in considering separately how sales and expense categories are affected by various exchange rate scenarios. The second one consists in running a regression analysis to historical cash flow and exchange rate data.

To asses transaction exposure, the firm needs to (1) estimate its net cash flows in each currency and (2) measure the potential impact of the currency exposure. Value at risk is a well-known method to assess transaction exposure. According to Khazeh, Salimian, Winder (2012) the Value-At-Risk (VAR) technique has become one the most accepted approaches to assessing transaction exposure. The VAR methodology can be engaged to appraise the maximum likely loss on the value of the MNC's net cash flows denominated in one or more foreign currencies for a given time period. The desired time period can vary from as short as 1-day (in this study) to as long as 1-week, 1-month or even longer. The estimates of the maximum loss can then be used to assess if hedging is desirable.

Holton (2003) says that the VAR calculation depends on 3 parameters: (a)The holding period, i.e., the length of time over which the foreign exchange position is planned to be held. The typical holding period is 1 day. (b) The confidence level at which the estimate is planned to be made. The usual confidence levels are $99 \%$ or $95 \%$, and (c) the unit of currency to be used for the denomination of the VAR.

This method has some limitation. According to Madura (2008) the VAR method presumes that the distribution of exchange rate movements is normal. If the distribution is not normal, the maximum of expected loss is subject to error. VAR method also assumes that the standard deviation of exchange rate movements is stable over time. If exchange rate movements are less volatile in the past than in the future, the estimated maximum expected loss derived from the VAR method will be underestimated.

Hagelin and Pramborg (2004) suggest that there are risk reducing effects from transaction exposure hedges as well as from translation exposure hedges. A possible explanation for the latter is that translation exposure approximates the exposed value of future cash flows from operations in foreign subsidiaries (i.e. economic exposure). If so, by hedging translation exposure, economic exposure is reduced.

A common question that rises is whether exchange rate risk is relevant. Thus, is it worth to spend time and money to hedge it? According to Madura (2008) exchange rate risk is not relevant according to purchasing power parity (PPP) theory (exchange rate movements are just a response to differentials in price changes between countries. Therefore, the exchange rate effect is offset by the changes in prices). But PPP does not necessarily hold, so exchange rate will not necessarily change in accordance with inflation differential.

Another irrelevance is that investors in multinational companies can hedge exchange rate risk on their own, but investors prefer that corporations perform the hedging for them.

Currency diversification is another argument. If a multinational company is well diversified across numerous countries, its value will not be affected by exchange rate movements, because of offsetting effects. But it is naive to presume that exchange rate effects will offset each other just because a multinational company has transactions in many countries.

Some critics also argue that if stakeholders are well diversified, they will be somewhat insulated against losses experienced by a multinational company due to exchange rate risk. But it is difficult to compose a diversified portfolio of stocks that will be insulated from exchange rate movements. For these reasons, exchange rate risk is relevant and should be assessed and hedged if necessary.

Eun, Resnick (2004) say that to hedge economic exposure, the firm can use different strategies such as selecting low-cost production sites. The firm can choose to locate its production facilities in a foreign country where costs are low due to either the undervalued currency or underpriced factors of production. The firm can also try to maintain flexible 
sourcing policy, diversification of the market, product differentiation, or financial hedging using currency options or forward contracts.

Transaction exposure can be hedged by financial contracts and operational techniques. Financial contracts consists of forwards, money market, option, and swap contracts, as well as by operational techniques as the choice of invoice currency, lead/lag strategy, and exposure netting.

Forward contracts are the most common means of hedging transactions in foreign currencies. The trouble with forward contracts, however, is that they require future performance, and sometimes one party is unable to perform on the contract. When that happens, the hedge disappears, sometime at great cost to the hedger. This default risk also means that many companies do not have access to the forward market in sufficient quantity to fully hedge their exchange exposure. For such situations, futures may be more suitable. Forward are usually offered from banks. Commercial banks in Albania are not allowed to offer forward contracts with maturity longer than one day. They have to close out the position within the day. Thus these instruments cannot be used from our businesses yet. Outside of the interbank forward market, the best-developed market hedging exchange rate risk is the currency futures market. In principle, currency futures are similar to foreign exchange forwards in that they are contracts for delivery of a certain amount of a foreign currency at some future date and at a known price. In practice, they differ from forward contracts in important ways. Futures are traded in financial exchanges. Developed financial exchanges do not offer futures on lek currency, and Tirana stock exchange still does not trade these instruments. Thus our firms still cannot use futures.

Money market hedging consists of lending and borrowing in the domestic and foreign money markets. Generally speaking, the firm may borrow (lend) in foreign currency to hedge its currency receivables (payables), thereby matching the assets and liabilities in the same currency. This is a strategy that Albanian firms can execute.

Many companies, banks, and governments have extensive experience in the use of forward exchange contracts, whereas currency options-or option contracts in general- are still used far less frequently. However, as market participants have developed a better understanding of option pricing, trading, and hedging of options positions over the last couple of years, the use of options has become more frequent. But yet, far away for Albanian firms to be understood and used. By using options firms can still benefit from favorable moves of exchange rates, unlike forwards and futures.

Firms often have a sequence of accounts receivables or payables in a foreign currency. These cash flows can be hedged using a currency swap contract, that is an agreement to exchange one currency for another at a given exchange rate. This is called the swap rate and these contracts are known as swap contracts.

Invoice currency hedging is an operational hedging technique. The firm can shift, share or diversify exchange risk by appropriately choosing the currency of invoice.

A firm will "lead" (to pay or collect early) soft currency receivables, and "lag" (pay or collect late) hard currency receivables to avoid the loss from depreciation of the soft currency and benefit from appreciation of the hard currency, For the same reason, the firm will try to lead the hard currency payables and lag soft currency payables. In this way the transaction exposure the firm faces can be reduced. This is a strategy that firms in Albania can use.

Exposure netting, means that the firm should hedge residual exposure, rather than hedge each currency position separately.

Two ways to control translation risk are: a balance sheet hedge and a derivatives "hedge". Since translation exposure does not have an immediate direct effect on operating cash flows, its control is relatively unimportant in comparison to transaction exposure, which involves potential real cash flow losses. Since it is, generally, not possible to eliminate both translation and transaction exposure, it is more logical to effectively manage transaction exposure, even at the expense of translation exposure. (Eun, Resnick 2004). As firms in Albania do not have foreign subsidiaries, they do not face this kind of exposure.

\section{Methodology and results}

In this paper we tried to find out the exchange exposure of the firms in Albania, what kind of exposure that is, and how the firms can hedge it. We considered a case study consisted of an Albanian firm operating in Shkodra. For sure we cannot generalize our findings, but at least we can make an idea and also show how firms should determine the exchange risk they face.

The firm was selected randomly and we interviewed the representatives and also got the financial statements and data needed for our analysis.

The firm is an insurance company. All the prices for the services offered were set in euros. So, if one wanted to pay in lek, he had to convert the leks to euros with an exchange rate offered from the firm. In this way, the firm was hedging the transactional exchange exposure, while the client was facing it. Table one gives the income generated from 
sales in euros from January 2011-September 2011 and the exchange rates used from the firm (which is determined from the beginning of the month and used throughout the month) and the exchange rate declared from the Center Bank of Albania at the end of the month.

Table 1.

\begin{tabular}{|l|c|c|c|c|c|c|c|}
\hline $\mathbf{2 0 1 1}$ & $\begin{array}{c}\text { Income from } \\
\text { sales in } \\
\text { euros (1) }\end{array}$ & $\begin{array}{c}\text { Firm's } \\
\text { exchange } \\
\text { rate(2) }\end{array}$ & $\begin{array}{c}\text { Central Bank's } \\
\text { exchange rate (end } \\
\text { of the month) (3) }\end{array}$ & $\begin{array}{c}\text { Change in } \\
\text { percentage of the } \\
\text { exchange rate }\end{array}$ & $\begin{array}{c}\text { Sales in lek } \\
(\mathbf{1 x 2})\end{array}$ & $\begin{array}{c}\text { Change in } \\
\text { percentage of } \\
\text { the sales }\end{array}$ & $\begin{array}{c}\text { Sales in lek } \\
(\mathbf{1 \times 3})\end{array}$ \\
\hline January & 4754.33 & 139 & 139.31 & & $660,851.87$ & & $662,325.71$ \\
\hline February & 1806 & 139 & 139.92 & $0.44 \%$ & $250,986.74$ & $-62.02 \%$ & $252,647.95$ \\
\hline March & 3620 & 139 & 140.57 & $0.46 \%$ & $503,156.37$ & $100.47 \%$ & $508,839.50$ \\
\hline April & 6447 & 140 & 142.4 & $1.30 \%$ & $902,552.00$ & $79.38 \%$ & $918,024.32$ \\
\hline May & 3677 & 141 & 142.1 & $-0.21 \%$ & $518,430.21$ & $-42.56 \%$ & $522,474.70$ \\
\hline June & 4115 & 142 & 141.4 & $-0.49 \%$ & $584,301.60$ & $12.71 \%$ & $581,832.72$ \\
\hline July & 14740 & 142 & 140.19 & $-0.86 \%$ & $2,093,051.60$ & $258.21 \%$ & $2,066,372.56$ \\
\hline August & 19465 & 140 & 140.44 & $0.18 \%$ & $2,725,076.20$ & $30.20 \%$ & $2,733,640.73$ \\
\hline September & 5540 & 140 & 140.95 & $0.36 \%$ & $775,600.00$ & $-71.54 \%$ & $780,863.00$ \\
\hline
\end{tabular}

We have run a regression analysis to see whether the firm faces economic exposure.

$$
y=\alpha+\beta x
$$

If the coefficient before the independent variable is significant, then the firm faces economic exchange exposure. So, we have the following hypothesis:

$\mathrm{HO}: \beta=0$ and $\mathrm{Ha} \beta \neq 0$

After running the regression analysis between percentage change in the direct exchange rate of lek/euro and change in percentage of sales generated in euros and converted to lek (with the firm's stated exchange rate), we have the following relationship:

$$
\begin{aligned}
& y=0.458-51.849 x \\
& R^{2}=0.1003
\end{aligned}
$$

Now we have to test the coefficient of the independent variable for its significance. We will compare the t-statistic to the critical value (from the t-table) to determine whether the coefficient differs significantly from the values stated in the hypotheses. The results will be interpreted with Fisher distribution and Student distribution. We will use the ANOVA table and table of coefficients for statistical purposes. We will be using a confidence level of $95 \%(P>0.05)$.

\section{Figure 1.}

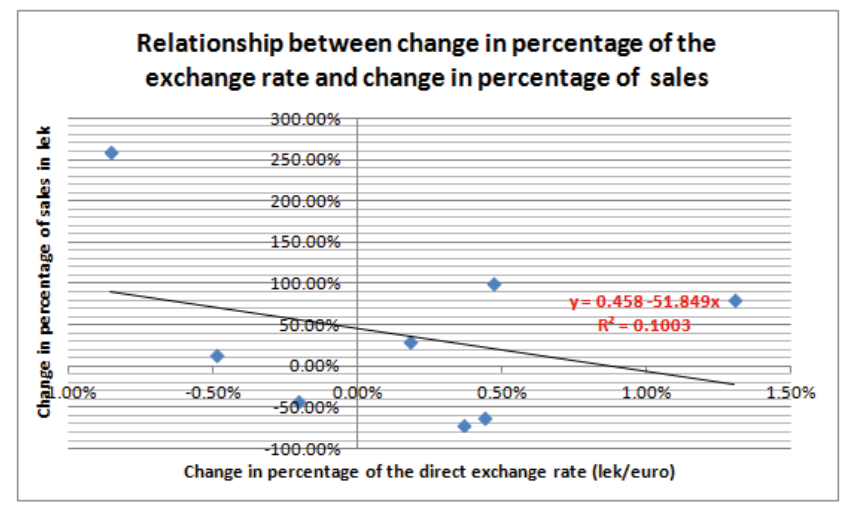

From the regression results, the t-statistic for the coefficient of the independent variable is -0.81806 , which is less than the critical value 2.447 , and $\mathrm{P}$ value $=0.444590758>0.05$. In this way we cannot reject $\mathrm{H}_{0}$ with $95 \%$ confidence level. 
Thus, the coefficient is not significant; it is not statistically different from zero. From this, we can conclude that the firm does not face economic exposure.

Table 2. Summary output of regression analysis of the firm

\begin{tabular}{|c|c|c|c|c|c|c|}
\hline \multicolumn{2}{|l|}{ Regression Statistics } & & & & & \\
\hline Multiple R & 0.31677105 & & & & & \\
\hline R Square & 0.100343898 & & & & & \\
\hline Adjusted R Square & -0.049598786 & & & & & \\
\hline Standard Error & 1.117612632 & & & & & \\
\hline Observations & 8 & & & & & \\
\hline \multicolumn{7}{|l|}{ ANOVA } \\
\hline & $d f$ & SS & $M S$ & $F$ & Significance $F$ & \\
\hline Regression & 1 & 0.835888386 & 0.835888 & 0.669215033 & 0.444590758 & \\
\hline Residual & 6 & 7.494347965 & 1.249058 & & & \\
\hline \multirow[t]{2}{*}{ Total } & 7 & 8.330236351 & & & & \\
\hline & Coefficients & Standard Error & $t$ Stat & $P$-value & Lower 95\% & Upper $95 \%$ \\
\hline Intercept & 0.457972761 & 0.406167521 & 1.127546 & 0.302573188 & -0.535883359 & 1.451828881 \\
\hline Change in $\%$ of Ex.Rate & -51.84938089 & 63.38123994 & -0.81806 & 0.444590758 & -206.937688 & 103.2389262 \\
\hline
\end{tabular}

We will continue the analysis with this firm to assess transaction exposure based on value at risk (VAR). This method measures the potential maximum one-day loss on the value of position of the firm that is exposed to exchange rate movements. If the percentage changes of the exchange rate are normally distributed, the maximum one-day loss is determined by the left tail (the lower boundary) of the probability distribution. If we consider 95 percent confidence level, the maximum one-day loss is going to be about 1.65 standard deviations away from the expected percentage change of the exchange rate.

Maximum one-day loss $=\mathrm{E}\left(\mathrm{e}_{\mathrm{t}}\right)-\left(1.65 \times \sigma_{\text {euro }}\right)$

If we have a look at the exchange rate of lek/euro for the period from January $1^{\text {st }} 2013$ to April $30^{\text {th }}$, and calculate the standard deviation of the percentage change of this exchange rate, we will have a value of $\sigma=0.175 \%$. Suppose that we are not expecting a change in the exchange rate for the next day, thus $E\left(e_{t}\right)=0 \%$. The maximum oneday loss is going to be:

$$
\begin{aligned}
& \text { Maximum one-day loss }=0 \%-(1.65 \times 0.175 \%)=-0.28875 \% \\
& \begin{aligned}
\text { Euro value based on maximum one-day loss } & =\text { Spot Rate } \times\left[1+\mathrm{E}\left(\mathrm{e}_{\mathrm{t}}\right)\right] \\
& =138.179 \times[1+(-0.0028875)] \\
& =137.78 \text { lek/euro }
\end{aligned}
\end{aligned}
$$

If the maximum one-day loss occurs, the euro's value will have declined to 137.78 lek/euro. If the next day the firm is expecting to get 10,000 euros, which today represents $100,000 \times 138.179=13,817,900$ leke, with a decline of $0.28875 \%$ we will have a loss of $13,817,900 \times(-0.28875 \%)=39,899.19$ leke. This is up to the firm if this amount is large enough in order to decide whether or not to hedge it.

We can use VAR method to assess exposure even over longer time horizons. To apply VAR for longer time horizons, we have to estimate the standard deviation over the time horizon in which the maximum loss is to be measured. First, we calculated the standard deviation of the monthly percentage change of the exchange rate from January 2004 to September 2011. It resulted equal to $1.0555 \%$. After that we estimated the euro value of the maximum one-month loss according to VAR method with $95 \%$ confidence level. The results are shown in table 3 . According to our calculations the firm is exposed to exchange rate risk, as euro can depreciate.

To continue with exchange rate exposure analysis we will have to estimate the translation exposure. The degree of translation exposure is dependent on the proportion of the business conducted by foreign subsidiaries, the location of the foreign subsidiaries and the accounting method used. Firms operating in Albania are mainly domestic firms, which do not have subsidiaries in other countries, thus they do not face translation exposure. 
Table 3.

\begin{tabular}{|l|c|c|c|c|c|c|}
\hline $\mathbf{2 0 1 1}$ & $\begin{array}{c}\text { Income from } \\
\text { sales in euros } \\
(\mathbf{1})^{*}\end{array}$ & $\begin{array}{c}\text { Firm's } \\
\text { exchange } \\
\text { rate(2) }\end{array}$ & $\begin{array}{c}\text { Central Bank's } \\
\text { exchange rate (end } \\
\text { of the month) (3) }\end{array}$ & $\begin{array}{c}\text { Expected change in percentage } \\
\text { change of the exchange rate } \\
\text { from firm perspective** }\end{array}$ & $\begin{array}{c}\text { Max one } \\
\text { month } \\
\text { loss }\end{array}$ & $\begin{array}{c}\text { Euro value of } \\
\text { the max one } \\
\text { month loss }\end{array}$ \\
\hline January & 4754.33 & 139 & 139.31 & & & \\
\hline February & 1806 & 139 & 139.92 & $-0.2225 \%$ & $-1.9640 \%$ & 136.5739 \\
\hline March & 3620 & 139 & 140.57 & $-0.6575 \%$ & $-2.3990 \%$ & 136.5633 \\
\hline April & 6447 & 140 & 142.4 & $-0.4055 \%$ & $-2.1470 \%$ & 137.552 \\
\hline May & 3677 & 141 & 142.1 & $-0.9831 \%$ & $-2.7247 \%$ & 138.5201 \\
\hline June & 4115 & 142 & 141.4 & $-0.0704 \%$ & $-1.8119 \%$ & 139.5253 \\
\hline July & 14740 & 142 & 140.19 & $0.4243 \%$ & $-1.3172 \%$ & 139.5375 \\
\hline August & 19465 & 140 & 140.44 & $-0.1355 \%$ & $-1.8770 \%$ & 137.5586 \\
\hline September & 5540 & 140 & 140.95 & $-0.3133 \%$ & $-2.0548 \%$ & 137.5542 \\
\hline
\end{tabular}

* Suppose these are expected cash flows to be received

** $\left((2) \mathrm{t}_{1}-(3) \mathrm{t}_{0}\right) /(3) \mathrm{t}_{0}$

\section{Conclusions and Recommendations}

Firms engaged in international businesses or not do face exchange rate risk. This is the possible loss in value of the firm, or loss in cash flows received or loss in translation. The types of exchange rate exposures that the firms face are economic exposure, transaction exposure and translation exposure. The main technique to measure the economic exposure is to run a regression analysis between change in percentage of cash flows or income, or sales and the change in percentage of exchange rate. Whereas, assessing the transaction exposure is the value at risk technique.

Economic exposure can be defined as the extent to which the value of the firm would be affected by unexpected changes in exchange rates. Transaction exposure is defined as the sensitivity of realized domestic currency values of the firm's contractual cash flows denominated in foreign currencies to unexpected exchange rate changes. Translation exposure, on the other hand, refers to the potential that the firm's consolidated financial statements can be affected by changes in exchange rates.

The firm is subject to a transaction exposure when it faces contractual cash flows denominated in foreign currencies. Transaction exposure can be hedged by financial contracts like forward, money market, and options contracts, as well as by such operational techniques as the choice of invoice currency, lead/lag strategy, and exposure netting.

The currency that Albanian firms are most exposed to, is the euro. This is because most businesses that Albanian firms deal with come from the Eurozone.

The firm considered in this paper does not face economic exposure. In general, firms in Albania do not face economic exchange risk, because there are mainly domestic firm operating in different sectors. An exception is the bank sector where there are mostly foreign owning banks. But, these are all affected in the same way from euro exchange rate.

Firms do face transaction exposure. They use operational techniques to hedge this risk exposure, but they cannot use financial instruments. The first reason is due to lack of financial knowledge, and the second reason is that our currency lek, is a minor currency. Forward contracts are not offered from our commercial banks and futures on this currency do not trade in foreign exchange markets.

Firms should know and assess the exchange rate exposure and find out instruments and techniques to hedge. Commercial Banks in Albania should start offering forward contracts, so that firms can hedge their transaction exposure by using financial instruments.

\section{References}

Adler, M., Dummas, B. (1984). Exposure to currency risk: definition and measurement. Financial Management, Summer, pp 41-50. Allayannis, G., Ihrig, J., and Weston, J. (2001). Exchange-Rate Hedging: Financial vs. Operational Strategies. American Economic Review Papers and Proceedings, 91 (2), pp. 391-395.

Campbell, J. Y., De Medeiros, K. S., Viceira, L. M. (2010). Global currency hedging. The Journal of Finance, Vol. LXV, no. 1, pp. 87-121. Dufey, G., Giddy, I. H. (2003) Management of corporate foreign exchange risk. Chapter 6 in Choi, Frederick D.S., (3rd eds), International finance and accounting handbook, Hoboken, NJ: John Wiley \& Sons.

Eun, Resnick. (2004). International financial management, $4^{\text {th }}$ ed., (pp. 282-348). New York, NY: The McGraw-Hill Companies. 
Hagelin, N. Pramborg, B. (2004). Hedging foreign exchange exposure: risk reduction from transaction and translation hedging. Journal of International Financial Management and Accounting 15:1.

Heta, K. T., Kastrati, A., Saraçi, P. (2013). The exposure of construction firms in Shkodra region to the exchange rate risk and its hedging. Proceedings from Regional $3^{\text {rd }}$ Science Conference with International Participation: Effects of Global Risk in Transition Countries. Peja, Republic of Kosova.

Holton, G. A. (2003). Value-at-Risk: Theory and Practice. San Diego, California: Academic Press.

Khazeh, K., Winder, R. C., Salimian, F. (2012). Value at Risk and Transaction Exposure: Lexicographic Permutation of a Six-Currency Portfolio. The Journal of Current Research in Global Business, Vol. 15, No. 24; Fall: 20-31.

Madura, J., (2008). International financial management, $9^{\text {th }}$ ed. (pp. 280-306). Mason, OH: Thomson South-Western.

Papaioannou, M. (2006). Exchange rate risk measurement and management: Issues and approaches for firms. South-Eastern Europe Journal of Economics 2, pp 129-146.

Shapiro, A. C. (1996). Multinational Financial Management, $5^{\text {th }}$ ed. Hoboken, Ney Jersy: Wiley.

Stapleton, R. C., Subrahmanyam, M. G. (2003). Interest rate and foreign exchange risk management products: overview of hedging instruments and strategies, Chapter 7 in Choi, Frederick D.S. (3rd eds), International finance and accounting handbook, Hoboken, $\mathrm{NJ}$ : John Wiley \& Sons.

www.oanda.com/currency/historical-rates/ 